\title{
Differential translation
}

\section{A proposed strategy for translating polysemous language in German philosophy}

\author{
Spencer Hawkins \\ University of Michigan, Ann Arbor
}

Translators of German philosophy into English must often choose whether to express concrete or abstract meanings for polysemous German keywords. This article discusses "differential translation," a widely underestimated strategy for representing polysemous words in translation. Disavowing both untranslatability and the necessity of terminological equivalence, this strategy integrates signs of polysemy into the reading experience by presenting foreign keywords in brackets after their differing, context-dependent meanings. The article discusses how translators have already responded and how they might respond even more constructively to passages where Edmund Husserl, Martin Heidegger, and Hans Blumenberg, respectively, choose words that link abstractions to images: by presenting existence as both foundational and ground-like (gründlich), time as both fluctuating and fluid (strömend), and common sense as both obvious and nearby (naheliegend). Encountering differentially translated texts would challenge future scholars to evaluate the unity of the concepts behind the words.

Keywords: polysemy, phenomenology, metaphor, untranslatability, Heidegger, Blumenberg

\section{Introduction}

German and French words that gained prominence through translations of Continental philosophy texts now permeate the Anglophone humanistic disciplines and thus affect English language discourses around profound matters from theology to critical theory. ${ }^{1}$ German words often mean exactly what their etymologies indicate besides having other abstract meanings, more often than their English

1. Words that have come from translated Continental philosophy and acquired general use in humanistic scholarship (after being adopted by thinkers such as Judith Butler and Donna 
near equivalents do. Context does not always differentiate between concrete or abstract meanings for polysemous German words. These words thus become a great challenge to translators of German philosophy. For instance, German's productive über- (over) and unter- (under) prefixes contribute to Friedrich Nietzsche's vivid style in Thus Spoke Zarathustra. The German verb untergehen bears the etymological sense "to go under" (concrete), but it commonly means "to meet your demise" (abstract), reflecting the cross-cultural tendency to figure hardship with the "orientational metaphor" of low altitude (Lakoff and Johnson 1980: 196). Since polysemous German words can express unified concepts where the target language differentiates between multiple concepts, I propose translating such words differently by context throughout the text, and presenting them in parentheses after each translation. I call this strategy "differential translation" since it differentiates words' dual (or various) concrete and abstract meanings.

Many philosophers dub words "untranslatable" on the basis of indeterminate meaning alone. ${ }^{2}$ When polysemous words' meanings shift by context within texts, the difficulties mount. Yet some argue quite rightly that the proliferation of "untranslatable" words need not deter the work of translation; rather, it requires responsiveness to the particularity of texts. ${ }^{3}$ Differential translation works analogously to differential functions in calculus, which measure the rate of change within physical processes, such as the changing rate at which water dissolves as its temperature increases. The source text and the timespan of a physical process are the analogous objects; differential translation registers the changes in meaning of a word in the source text, just as a differential function measures the changes in rate of a physical process. Differential translation thus tests words for meaning variance by sentence context. Translating different occurrences of a word (untergehen) in a text differently displays a word's differentiated meanings ("descend" when Zarathustra leaves his mountain hermitage, "meet [your] demise" when untergehen becomes his controversial moral advice). ${ }^{4}$ Translating a word differentially

Haraway) include: "problematic" (Kant, Althusser), "lifeworld" (Husserl, Habermas), and the gerunds "Being" and "Becoming" (Heidegger, Deleuze).

2. Le pain for Benjamin, to season for Derrida, cheese for Jakobson, and gavagai for Quine only require one ambiguous context each to exemplify translation problems (Benjamin 2000; Derrida 2001; Jakobson 1971; Quine 1960).

3. (Beals 2014) and (Koller 2004) argue through readings of Paul Celan and J. R. Ladmiral respectively that "untranslatables" are no longer impediments to translation when these authors' works are studied at the level of text rather than lexeme.

4. Walter Kaufmann translates untergehen consistently as "to go under" (Nietzsche 1995: 10,15). His choice produces a reader friendly text, but differential translation would even more clearly show Nietzsche's imaginative wordplay. 
attempts to recreate a foreign culture's experience of meaning. It expands the reader's context much like glosses and annotations, the familiar academic strategies for achieving culturally mediating "thick translation" (Appiah 1993: 817). Differential translation is an especially promising way to convey linguistic difference because it integrates signs of difference into the reading experience.

Robert Adams' translation of the lexeme virtù in Nicolo Machiavelli's The Prince is one of the clearest published examples of differential translation. Virtù is the kind of polyvalent concept that Barbara Cassin might call an "untranslatable." Macchiavelli uses it to designate the polymorphous character trait whose effect is the acquisition of political power; the fact that virtü's presence can only be assessed post hoc foils attempts to characterize it beyond its particular manifestations. The translator translates it four different ways on the same page: first as "strength" when contrasting it with "luck:" "I'd like to illustrate these two ways of becoming prince, by strength [virtù] or by luck..." (Machiavelli 1977: 19). Then he selects "shrewdness," a seemingly distinct trait, to describe how Francesco Sforza "used the appropriate means with great shrewdness [virtì] to become duke of Milan." Its adjectival form, virtuoso, is translated as "able," a trait which may or may not be a matter of luck. Last, virtù as "effort," inflects how one reads the other translations: the earlier tokens of virtù refer to deliberately applied qualities, as opposed to passively reproduced ones. By not settling on one English equivalent for virtù, differential translation presents virtù as a polysemous word for a polyvalent concept.

To my knowledge, only one recent study has expressed the advantages of differential translation. David Charlston praises nineteenth-century translator, Sir James Black Baillie, for using both "mind" and "spirit" when translating Geist in G. W. F. Hegel's Phenomenology of Spirit (Charlston 2014: 15). Inconsistent translations of keywords without the source word in brackets notoriously causes other critics irritation. Jean Laplanche criticizes James Strachey for translating Sigmund Freud's Nachträglichkeit as context dictated, with "later," "belatedly," and "deferred action" among other words; in such a translation, a supposedly unified concept is "diffracted in different contexts and it gives the illusion that there are several meanings" (Laplanche 1993: 42). I will respond further to Laplanche's criticism after arguing that ambiguous concepts deserve such diffraction, that the German philosophical language is rich in ambiguous concepts, and that including source words in brackets does not make a diffractive translation but a differential one.

Both for reasons of linguistic history and of genre, the language of German philosophy works closely with untranslatable etymological figures. German language philosophy exhibits a higher degree of polysemy than its English counterpart for three notable reasons: (1) German words are constructed from Germanic roots, and thus their etymologies are transparent to native speakers - unlike English, where erudite vocabulary often comes from Greek and Latinate roots, 
which severs the associative links between concrete (handy, Germanic) and abstract (dexterous, Latinate). As a result, many German words present native speakers with a greater number of easily registered connotations than English ones. (2) The total number of words available in English is greater than in German, with the result that German words often denote more different concepts than English ones. And (3) phenomenology, a philosophical sub-field developed in Germany, focuses on notoriously difficult phenomena to define, such as time, subjectivity, and other general features of experience. Given their difficult task, twentieth century German phenomenologists offer various justifications for utilizing the suggestiveness of German etymologies to illustrate their abstract concepts. Martin Heidegger's etymological figures are well known, but this article will show why etymology also matters when translating work by other phenomenologists whose rhetorical styles and theory of languages differ from Heidegger's. The article focuses on three philosophers: (1) Heidegger, (2) Edmund Husserl, under whom Heidegger studied, and (3) Hans Blumenberg whose teachers (Ludwig Landgrebe and Walter Bröcker) had themselves studied under Husserl and Heidegger, respectively. These three philosophers' texts link abstractions to images: by presenting existence as foundational and ground-like (gründlich), time as fluctuating and fluid (strömend), and common sense as obvious and nearby (naheliegend).

German philosophers tend to develop concepts with a wider range of meanings than English-speaking philosophers do because the German language imbues its fewer words with more meanings through transparent etymology. This situation contributes to readers' frustration with English translations of German philosophy. Translators can relieve some frustration by exposing ambiguous words. This article reviews extant strategies for capturing implicit imagery when translating Heidegger, Husserl, and Blumenberg. For these authors, etymology suggests a logic of images alongside the logic of the argument. ${ }^{5}$ Figurative associations form a "dimension of argumentation," which translators omit at the cost of the "destruction of underlying networks of signification" (Berman 2000:292-3). Translators of such texts have a double task: to present overt claims while also registering keywords' suggestive polysemy.

These three philosophers multiply the suggestive etymologies of Strom, Grund, and liegen by exploiting both the productivity of German word compounding and polysemous morphology. Husserl selects a compound word to designate

5. Jacques Derrida's deconstructive enterprise draws heavily from the latent metaphors in Husserl's work and in Heidegger's, such as Husserl's figuration of primary phenomena as inner voice, and existence as being there in Heidegger (Derrida 1973; 1991). Derrida claims that these images reveal moments where these thinkers covertly insert empirical evidence into claims about structures (consciousness or Dasein) that are supposed to function a priori. 
the ever changing content of consciousness: the "stream of consciousness" (Bewußtseinsstrom). Strom denotes a surging force, and only in this compound does it refer to the abstract idea of consciousness's fluctuating content. ${ }^{6}$ With an aversion to fluid imagery, Heidegger names the lack of rationale for the fact that something exists (rather than nothing) with a topographical image: the "abyss of Dasein" (Ab-grund des Daseins). Etymologically, Ab-grund means an absent ground, and the hyphen emphasizes $A b$-grund as separate from grounds, thus without rationale. While Husserl embraces his metaphor, Heidegger deemphasizes the concrete abyss image - a giant hole in the ground - since it could give Heidegger's speculation about existence the sound of imprecise metaphor.

Furthermore, Abgrund suggests a mystical force, Strom a natural one, naheliegend an everyday phenomenon. Christian theology preserves connotations of "abyss" dating back to the mythical Greek Tartarus, the abyssal origin of the world and a site of afterlife punishment. Heidegger's language often suggests archaic or religious images of suffering, sacrifice, and apocalyptic revelation (See Stellardi 2000: 159). While "proximity" is a cross-cultural "orientational metaphor," too ordinary for its discursive history to be traced, German etymology animates the concept in the word naheliegend, which means "obvious," but whose etymology means "lying nearby." Blumenberg does not treat it as a term, but it is his chosen word to describe the stars' distance from earth when that distance figures for disciplines like astronomy and philosophy, which appear irrelevant to worldly affairs (because their relevance is not "obvious"). Blumenberg lets the syntactic context dictate whether the word carries its abstract denotative meaning, "obvious," or its concrete spatial etymology, "lying nearby." In all three cases, English cognates of the German words translate the image (ground, stream, and near) whereas Latinate words convey the abstraction (reason, flux, and obvious).

When these philosophers orient their work around images, they also suggest different theories of mind. Grund: the mind possesses knowledge. Just as people claim land, people claim to have figurative "grounds" that give their arguments validity. Heidegger, whose academic training is in medieval Scholasticism, treats knowledge as predicative: we can have knowledge because objects have knowable properties. Strom: knowledge happens to the mind. Streams move, and when Husserl uses streaming time consciousness as the image for the subject, object, and process of knowledge, he makes knowledge into a time bound event that occurs independently of the knower. Knowledge occurs to the mind only to evaporate unpredictably, just as streams introduce water from elsewhere and then carry it

6. As Andrea Rehberg reminds me, Strom is the German word for the largest of rivers (and electricity). Its adequacy as a metaphor for time derives from its reference to an overwhelming force. 
away. Naheliegend: knowledge is a relationship to an object. To know is to give an object a place in our sphere of knowledge and thus to bridge the "ontological distance," which obscures objects by holding them out of our reach (Blumenberg 1950: 18-19). While these three concepts have not been thematized together before, they are among the paradigmatic metaphors that structure Continental philosophy. They also get lost in English translation when denotative meaning is expressed without conveying their image content.

\section{Grund, ground or reasons? (Heidegger)}

This section focuses on one translation choice that almost every translator of Heidegger approaches differently: expressing the polysemy of Grund. Heidegger's use of Grund is difficult to translate because he draws on suggestive connotations of the word while disavowing the use of metaphor and expressing contempt for translation. Translators and scholars have discussed Heidegger's difficult style and developed innovative strategies for translating it, some even resembling differential translation. ${ }^{7}$ Before discussing the strategies, it is important to discuss the complicating effect of Heidegger's stance on metaphor and translation. Heidegger disavows metaphor because he claims that metaphors imply that the abstract and concrete are essentially different, and metaphor is therefore complicit with the mistake of metaphysical dualist thinking. This disavowal can leave readers perplexed at Heidegger's heavy reliance on the concrete and abstract meanings of his keywords. It is difficult to avoid reading Grund as metaphoric in the contexts discussed below, but differential translation leaves it to the reader to evaluate the coherence of Heidegger's claim.

Der Satz von Grund (1955-56), Heidegger's lecture on the principle of sufficient reason, will be the main focus of this section. In it, Heidegger argues that the philosophical use of Grund historically derives from the Greek logos, and he denies any value to translating great poems or philosophy texts. Andrew Benjamin's book on translation and philosophy quite correctly diagnoses a disdain for polysemy behind Heidegger's disdain for translation since Heidegger imagines that Greek words such as logos and physis first functioned not as unstable signifiers, but as

7. The series Contributions to Phenomenology recently published a volume on philosophical questions surrounding the translation of Heidegger (Schalow 2011). A monograph argues that Heidegger must be translated with attention to the word, not the sentence, following the "paratactic method" that Heidegger uses to translate Parmenides (Groth 2004). Laurence Venuti claims that translating Heidegger benefits philosophers' "translatorly self-consciousness as well as... their own philosophical research" (1998: 119). 
expressions of the Greeks' openness to the unknown (1989:25-31). Polysemy resulted from a presumed Babel event (around $600 \mathrm{BC}$ ) where these words' mystical power was forgotten, and they splintered into unstable meaning (Heidegger 1991, Vol. 1: 149). The concealment of the origin and the proliferation of new meaning were both exacerbated by these words' later translation into Latin. In his Parmenides and Heraclitus lectures held in 1942-3 and in 1944 respectively, he carefully considers translations of each word within those authors' fragments while only tentatively arriving at full reconstructions of their sentences.

Despite its consistency with his post-metaphysical critique of metaphor, Heidegger's dismissive view of translation "foreswears one of his own most powerful philosophical methods, radical translation from Greek," in Douglas Robinson's words (Robinson 2001: 100). Robinson challenges Heidegger's stance against translation by translating a passage where Heidegger bans the translation of philosophy while simulating Heidegger's own aporetic translation procedure. Robinson translates it in three different ways: first straightforwardly, then playing up etymology at the expense of meaning, and, third, by inserting sarcastic commentary on Heidegger's mysticism. The triple translation functions as commentary; the main effect of its plurality is to reenact Heidegger's aporia around translation choices. Robinson is not attempting a standard translation of Heidegger's language; rather, he is communicating Heidegger's thought (a procedure he calls "spirit-channeling," which he claims Heidegger also performs). Differential translation might not please Heidegger, who disdained "calculative thinking" and its effects on language. Unlike the total deferrals of spirit-channeling, differential translation only disturbs the unitary surface of the source text at the site of particularly suggestive polysemous words. ${ }^{8}$

Although Heidegger would certainly not accept my solution, he might acknowledge that untranslatability is primarily a lexical problem - not a grammatical one. Heidegger discusses the untranslatability of the lexeme Grund in Der Satz vom Grund, the text from which Robinson selects to perform his polemical translation. Heidegger's text, originally a lecture from $1955-56$, offers a corrective interpretation of the so-called "principle of sufficient reason" (der Satz vom Grund, etymologically translated, "the setting of the ground"). This principle states that nothing is without a reason (or ground). Leibniz understands the principle to mean that causal explanations both exist and may be discovered for all physical and psychological phenomena (ratio fiendi) as well as for metaphysical truth (ratio essendi). Heidegger counters that rational explanations fall short of explaining existence. The

8. What Robinson calls "spirit-channeling” resembles Paul Ricoeur's "never finished" translation, as Lisa Foran describes it: "Ricoeur explicitly links justice with the need to mourn the perfect translation" (Foran 2015:40). Both emphasize the authentic experience lost in translation. 
world - anything contained in it - exists, but Heidegger considers this inexplicable by causal explanation, which is limited to describing the rational realm. Heidegger thinks of the Grund for existence as a quasi-physical ground, not as a cause. As Heidegger scholar Nicholas Rand puts it, "Heidegger treats words as repositories of unseen or submerged meanings" (1990:437). And as the translator of "The Principle of Ground" explains: "Heidegger wants us to hear this principle 'in a different key,' and for this we must hear it as the principle of ground" (1974:207). Inspired by a similar insight, the translator Richard Taft uniformly renders Grund as "ground" (never "reason") in translating Heidegger's 1929 lecture (1997). But only translating Grund as "ground" misses a rhetorical dimension of Heidegger's text. In doing so, we miss the moments of shifting meaning that Heidegger effects between the one understanding of Grund and the other. Such differentials of meaning across a text are precisely what a technique like differential translation exhibits.

In efforts to grapple with Heidegger's language of "grounding," two translators have published translations of Der Satz vom Grunde with different titles: The Principle of Ground and The Principle of Reason (Heidegger 1974; Heidegger 1996). Der Satz vom Grund confronts the polysemy of Grund at length: besides meaning causal "reasons" - causes behind effects (ratio fiendi) and reasoning behind claims (ratio cognescendi) - Grund refers to the ground, the sea floor, and (in the "Allemanic-Swabian" dialect) to "heavy, fertile soil" (1996: 96). Importantly for his interpretation of "the principle of reason" (to be discussed below), Heidegger traces the etymology of the German word Grund to the Latin ratio, which had a different polysemy, both the faculty of reason and reason in the sense of causal force. Ratio often translates the Greek logos, which Heidegger understands not as speech, but as "let[ting] something appear." (1996:107). Grund is thus a historical derivative of the Greek logos, where the former's meaning as "grounding" captures something kindred to the latter's meaning as "letting appear."

With so much focus on etymology in this lecture, it is suitable that Reginald Lilly translated the word Grund in this lecture with a technique closely akin to differential translation. He translates the full lecture under the title The Principle of Reason and varies the translation of Grund between "foundation," "ground," "grounds," "reason," "reasons," and, when the ambiguity is too essential to trust to the reader's memory of the polysemy evoked across different contexts, the disjunctive "ground/reason" is selected: "Being qua being remains ground-less (grundlos). Ground/reason (Grund) strays from being, namely, as a ground/reason that would first found being, it stays off and away" (1996: 111; German added). Lilly's disjunctive translation shows the dualism operating within Heidegger's term, but it would disorient the reader if the number of meanings in disjunction exceeded two. Lilly also refrains from putting the word in brackets, because we know from 
reading the translator's preface that this is the only word he translates differentially and that we are dealing with the same word twice when we read: "The principle of reason (Grund) as the ground/reason (Grund) of the principle - this confuses our ordinary cognition" (1996: 14; German added).

Differential translation could extend to register compound words containing Grund. When Heidegger explores the topographical suggestiveness of Grund in Being and Time, he produces a paradoxical image where Being is at once Grund and Abgrund (abyss): "The meaning of Being can never be contrasted with entities, or with Being as the 'ground' (Grund) which gives entities support; for a 'ground' becomes accessible only as meaning, even if it itself is the abyss (Abgrund) of meaninglessness" (2008: 193-4). The translators of Being and Time mark this untranslatable moment with a footnote: "Notice the etymological kinship between 'Grund' ('ground') and 'Abgrund' ('abyss')." Beginning in his earliest lectures, Heidegger emphasizes the etymology of Abgrund as an expression of Being's relationship to Grund by hyphenating the word as Ab-grund. "Ab" is a prefix, whose spatial connotations include distant position and downward sinking movement whereas the "a" in the English "abyss" is merely privative (from Middle English $a+$ bussos "without depth"). This hyphenation is so difficult to express in English that Terrence Malick paraphrases the single word Ab-grund with six English words: “... freedom is the abyss of Dasein, its groundless or absent ground. (...Freiheit [ist] der Ab-grund des Daseins)" (1969: 129; German 130). Malick's translation comes in a format that gives the whole source text, unlike the focused offerings that differential translation gives: his edition offers facing page source and target texts. This lets the reader compare more choices than the reader of differential translation could, but does not show the reader where to start.

Philological annotations may not be enough to show readers how ambiguously some concepts function. While disjunctive translation works well in cases where only two alternatives exist, Lilly resorts to something like differential translation to show how the meaning of Grund changes in the text. Facing page bilingual editions yield much for language students and philologically minded scholars, but they do not isolate translation choices. The reader can find Malick's thoughts on Grund and Abgrund in the appendix, but the reader would be served better by a translation that pointed out difficult decisions where they are made. Consistently translating Grund (and related composita such as Abgrund) with image rich translations (like Richard Taft) merely obscures the move between concrete and abstract meanings. Differential translation is more difficult to justify when translating Husserl since he announces whether his language is figurative or not. Yet Husserl too offers occasions for differential translation when he slips unannounced meanings into his terminology. 


\section{Strom, stream or flux? (Husserl)}

Metaphoric language does not particularly plague translators of Husserl. Husserl builds his terminology around a central hydrological metaphor: the fluctuating content of consciousness enters and leaves in a stream-like procession. Husserl evokes the physical properties of streaming water to describe how consciousness spans time, just as Heidegger links the unknown reason for the world's existence with the image of solid ground. Etymology opens up associations between these philosophers' terms and the concrete objects they evoke. Husserl not only likened so-called "internal time consciousness" to a moving current (Strom), he pursued its semantic implications: the present as headwaters, self-reflection as a shore, and conscious experience as swimming. ${ }^{9}$ In Husserl's case, the word Strom could also be translated as "flow" or "flux," which would signify a process of frequent, unpredictable change, whereas "stream" conveys an image: electricity or liquid surging forth while its surroundings remain stationary. ${ }^{10}$ Differential translation is only occasionally necessary when translating Strom in Husserl's writings since Strom usually functions for Husserl as a concrete image. This section will focus on Husserl's use of Strom, his meta-commentary on the term, and why translating Strom passes for unproblematic.

Husserl explains in the 1905 lecture series on internal time consciousness that describing consciousness as a "stream" (Strom) is a deliberate catachresis; that is, he applies a well-known word to signify an erstwhile inadequately designated concept. Since Husserl's "stream" metaphor is deliberately chosen as a metaphor, and not as a fixed term, accuracy obliges translators to accentuate the aquatic character of Strom. In contrast to Heidegger's historical-etymological ruminations, Husserl was committed to describing acts of consciousness in the best defined language possible, and thus every metaphor had to be marked as such. Husserl introduces catachresis only when no names are adequate in his 1905 lecture:

9. In his lecture series on internal time consciousness, the headwaters, or "original source" (Urquelle) of internal time consciousness is the "primal impression" (Urimpression) that "constantly rises up" in the present moment (Quoted in Tymieniecka 2006:367). In a posthumously published note, Husserl describes the lifeworld as "the living stream in which I swim" (Quoted in Blumenberg 2010:38). In Cartesian Meditations, Husserl develops the metaphor of the shore or island as a figure for the ego that observes its own stream of consciousness.

10. Dorian Cairns, a student of Husserl's, lists "flow" after "stream" as an acceptable translation for Strom in Husserl's work (1973: 108). Colin Smith translates Fluß as "temporal flux" in a reference to Husserl from Merleau-Ponty's Phenomenology of Perception, but leaves the verb for "streaming in" untranslated in the English as it appears in source text: “...(they sich einströmen, as Husserl says)..." (Merleau-Ponty 2002:xv). 
It is absolute subjectivity and has the absolute properties of something to be denoted metaphorically as 'flux,' (eines im Bilde als 'Fluß' zu Bezeichnenden) as a point of actuality, as a primal source-point, from which springs the 'now,' and so on. In the lived experience, we have the primal source-point and continuity of moments of reverberation (Nachhallmoment). For all this, names are lacking (Für all das fehlen uns die Namen).

$(1981: 286)^{11}$

John Brough's translation misses the point of Husserl's image of Flu $\beta$ in this paragraph; Husserl wants us to see consciousness as a river (Flu $\beta$ ), not just a "flux." 12 We are to picture a flowing shape, not just a process of fluctuation. Time's fluid nature has no basis in empirical experience, according to Husserl, but time consciousness resists more precise description. The connotations of flowing liquid are invited. For instance, the cohesion of water particles in a stream offers an implicit, provisional model for the cohesion of intentional moments we experience as sequential.

In the quote above, Husserl only provisionally designates inner time consciousness (inneres Zeitbewußtsein) as a river (Fluß) (elsewhere as a current (Strom)), but in his later work the image of flowing water becomes crucial for understanding Husserl's concept of self-reflection. The Cartesian Meditations describe reflection as the "splitting of the Ego" where "the phenomenological Ego establishes himself as 'disinterested onlooker,' above the naively interested Ego" (1977:35). In the first meditation, for instance, Husserl would extend the "stream" metaphor to include a metaphorical "island," which would also allow "the possibility of imagining the streaming of the stream of consciousness as observable" (116). Self-reflection is figured as a view on the stream where the viewing self identifies with the stream. In the fifth Cartesian Meditation, where he introduces the concept of "intersubjectivity," the streaming self occupies a fixed position as the I-pole across from other non-I-poles, just as rivers have fixed geographic indices relative to the land they border. The self remains fixed in its difference from things and others, just as a river remains different from the shore and from other rivers.

Yet in the 1905 lecture, the metaphor of streaming time still primarily refers to simple change of content. Thus he describes the cluster of past moments that accompany every Now: "Constantly flowing (ständig fließend), the impressional consciousness passes over into an ever fresh retentional consciousness” (1981:280).

11. Derrida notes this concession to indeterminacy in Husserl but finds it unpersuasive (Derrida 1973: 84 f.9). According to Derrida, the present moment could be understood through its difference from other moments - rather than through its enmeshment in a subject-object relation. This expands on Heidegger's case that Husserl's phenomenology has merely replaced the Cartesian God with the transcendental ego and thus covertly endorses metaphysical assumptions.

12. James Churchill translates this word the same way (Husserl 1964: 100). 
If there is one case for differential translation in Husserl's use of Strom, a case for translating Husserl's lexicon of streams and rivers without hydrological words, it would be in quotes like the one above where "constantly in flux" might better show that here Husserl also constructs non-hydrological images for time consciousness. The pages around this passage utilize a variety of images for time consciousness: fluid movement yields to solid or intangible descriptions such as the path of a comet, peripheral vision, and the resonance of a musical tone. It is not a clear choice, however, since the translator who selects "flux" over "stream" masks the problem that Husserl's use of Strom suggests an object not just a process.

A metaphor cannot be proven; it either persuades or does not. The stream of consciousness image assists Husserl in conducting the descriptive method announced already in Logical Investigations: to narrate internal experience through "descriptive and genetic analyses" that reveal the structures preceding the experience of logical judgment (Husserl 2001:49). Heidegger avoided these difficulties by abandoning Husserl's image of fluid consciousness and selecting an image that resembles the language of logical categorization: consciousness abides in a fixed position. Fluidity is incompatible with Heidegger's notion that human individuals and collectives are fixed in their exterior relationship to Being. As Blumenberg describes it:

Heidegger's 'consciousness' does not flow, it stands. It also does not stand by itself and not bent over itself; it is outside itself, as it finds itself to be pre-given in being-always-already with what it is not: the world. The unavoidability of expressing the time concept in a spatial metaphorics - which is in no way avoided in [Husserl's] metaphorics of the stream - receives a fundamentally static character.

(Blumenberg 2012: 126; my translation)

While Husserl figures the process of fluctuation with explicitly metaphoric river imagery, Heidegger models an "existential spatiality" without qualifying his use of positional imagery as metaphorical. Husserl cautiously marks his metaphors for experience as catachreses so that translators know to look for concrete English equivalents. By contrast, Heidegger's synthesis of concrete and abstract language spurs translators toward strategies such as differential translation. In both cases, the translator does best to pay attention to the actual use of imagery, and not to be seduced by the author's claims about what their words do or do not connote. As we will see in the next section, such vigilance is especially merited when the author uses a polysemous lexeme without thematizing it as a term. 


\section{Naheliegend, obvious or lying near? (Blumenberg)}

Hans Blumenberg is well known in Germany for developing a "metaphorology," a framework for analyzing the expressive function of recurrent metaphors in rationalistic discourses (See Haverkamp and Mende 2009). But little research exists on his own rhetoric as a writer. The German present participle naheliegend lacks an English equivalent. It ordinarily means "obvious," but Blumenberg sometimes evokes its etymological sense: "lying nearby." He oscillates between meanings unannounced and does not develop the word naheliegend into a technical term. There would be nothing amiss about translating the word differentially by context throughout single texts and between different ones. But differential translation - as I have defined it - would mean drawing attention to this foreign word by putting it in brackets at each occurrence in the target text, and the reader might not find this procedure justified with a non-terminological word in a philosophy text. It is still justifiable to use brackets around this word in Blumenberg's work both because it carries varied connotations and because of the importance of such "orientation metaphors" across the history of philosophy (Lakoff and Johnson 1980). Although the word naheliegend is not laden with a history of attention from philosophers, it is the only word under discussion in this article to have a closely related image - that of neighboring - listed in Cassin's Dictionary of Untranslatables. The dictionary's entry on "Neighbor" notes that nearness often fails to constitute the category of neighbor, so that spatial proximity cannot determine "who is included in the category of the Neighbor" when we hear the Christian injunction to love our neighbors (2014: "Neighbor"). Neighboring and nearness are polysemous words: laden with moral imperatives and the emotional connotation of "feeling close," respectively.

English speakers could easily misunderstand what Blumenberg is doing with the polysemy of naheliegend because proximity is not a familiar English language orientational metaphor for "obvious." Blumenberg is very precise in his selection among the various German words for "obvious." Husserl and Blumenberg often use the German word nearest in meaning to the English "self-evident" (selbstverständlich) to express unquestioned beliefs (See for instance, 1970:24; 1983:250). Other German words for "obvious" have etymologies suggestive of visual manifestation: offensichtlich, literally "open to sight" and ersichtlich, "sightably." While these sometimes translate as "obvious," they more often mean "apparent," "evident," or "clear." The polysemy of naheliegend lets Blumenberg play with readers' expectations about what should be obvious. By etymology, something merely "apparent" (offensichtlich) might disappear the next moment; something "lying nearby" (naheliegend) is inert and will thus remain apparent. 
It would be implausible to claim that naheliegend has as strong a philosophical importance for Blumenberg as selbstverständlich does. But naheliegend occurs in Blumenberg's work whenever he discusses one of his favorite figures for philosophy, namely, Plato's anecdote about the protophilosopher Thales of Miletus:

Why, take the case of Thales, Theodorus. While he was studying the stars and looking upwards, he fell into a well, and a neat, witty Thracian servant girl jeered at him, they say, because he was so eager to know the things in the sky that he could not see what was there before him at his very feet.

(1977: 174A 121; translation modified)

Blumenberg claims that the anecdote serves "to depict the confrontation between theory and the lifeworld" (2015:11). Naheliegend describes the "obvious" surroundings that Thales ignores when he tumbles into a well. Blumenberg even modifies a German translation that he quotes (without citing) elsewhere in order to insert the word "tangibly obvious" (Handgreiflich-Naheliegend) into the Theaetetus

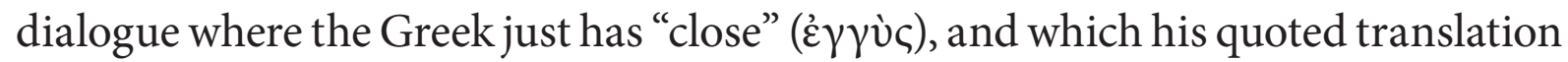
renders as "tangibly close" (Handgreiflich-Nah) (1987: 18; 1977: 121; 1940:58). This captures Blumenberg's conflation of the concept of "obvious" with the bodily experience of "near;" the well's nearness makes it a synecdoche for Thales' immediate surroundings, and to anyone else the proximate should be obvious.

In the passage from The Legitimacy of the Modern Age where Blumenberg describes Augustine's desire to control the discourse of astronomy, Robert Wallace translates naheliegend as "obvious:" "Augustine does not want his reader to be led to this obvious inference ([a]uf diese naheliegende Konsequenz)" (1983:309-310; 1966:295). Further down on the same page of the same book, Wallace translates that word as "nearest at hand" following the etymology that the sentence so strongly evokes: "The antithesis that pervades the tradition of curiositas since the anecdote about Thales between on the one hand what is nearest at hand (das Nächstliegende) and essentially urgent and on the other hand the humanely remote matters (das menschlich Fernliegende) that conceal the former is reoccupied here (bekommt hier eine neue Besetzung)" (1983:310; 1966:295). Wallace can ignore the primary meaning of the word naheliegend, as "obvious," since the next clause utilizes the notion of physical proximity to describe the source of obviousness in the sense of spiritual importance, of what should not be missed: "Now what is nearest at hand is the perception and acknowledgment of the dependence of one's own capacity for truth upon illumination." The concepts "obvious" and "near" prove fungible in describing the history of the Thales anecdote, and, without an English word possessing the same polysemy as naheliegend, only differential translation fully conveys this double meaning. 
In the previously-quoted passages, it made sense to translate the various inflections of naheliegend with "obvious" and "nearby," but as we saw with virtù in the introdution, differential translation does not only disambiguate meanings. How do we translate naheliegend to preserve the implicit distance metaphor when aspects of both meanings are at play? In the following paragraph about the Christian attitude toward transcendence, I have differentially translated three nominalized occurrences of naheliegend to capture a range of meanings:

If the Latin Patristic still accepts Ovid's account that humanity was bound to an upright gait with lifted head in order to observe the sky, then it becomes a metaphor: upon setting out toward the edge of the world, coming from what is familiar (Naheliegend), the observer of heaven is on the right path to transcend that edge. His plummet would represent the downfall of someone who had not wanted to go high enough, who grew weary already at the pagan foreground of the cosmic inner surface, and therefore failed to attain transcendence. The problem was not that he failed to understand the importance (das ihm Naheliegende) of the massiveness of the earth lying in front of his feet, but rather that he failed to understand the importance of caring about the base of all cares, his eternal salvation. Here the metaphorics of the distant correspond to those of the nearby (Nächstliegend), which no longer has any external reality; it has become the internal horizon of the truth seeker, who must now worry about himself.

(2015:30; second two German insertions added)

I translate the first occurrence of naheliegend with "familiar," rather than "obvious," since what is familiar is obvious as a result of past experience - which includes sensory experience. With "familiar," I express "obvious" and the image of leaving the world behind (since the world is not without surprises but is familiar as a context - compared to whatever "transcends that edge"). Two sentences later, naheliegend occurs and means "importance," in a context where "in front of his feet" is already given and "obvious" would not capture the valence here: das ihm Naheliegende is what he should have seen, what would have been important to pay attention to. Only in the third instance does "nearby" fit since the stars' distance is explicitly contrasted with das Nächstliegende. This keyword ranges in meaning, but translating naheliegend as "nearby" within a context of differential translation reminds the reader that the concept (whose continuity is indicated by the brackets) describes a sensory experience, and sensory experiences never enter language without acquiring symbolic functions. 


\section{How to translate untranslatables}

This article's proposal of differential translation as a general strategy for translating polysemous language may strike some readers as parochial. A sophisticated theory of translation should allow for a proliferation of strategies to represent different translators' perspectives on different projects rather than dubbing method A superior to B (See Robinson 1991). Differential translation has at least two obvious downsides. The discovery of meaningful etymologies could fall prey to "the explorer's illusion," which Gérard Genette describes as "the translator's temptation... to take these clichés [dead metaphors] literally and to render them in the translated version by figures that are not in common use" (Genette 1997: 218). Even Genette acknowledges that this is often better than eliding key connotations. Besides the exoticizing risk, exposing the shifting meanings of words across texts and reminding readers that they are reading a translation surely interrupts any immersive plaisir du texte and at best replaces it with a joltier jouissance. ${ }^{13} \mathrm{~A}$ text can rarely offer both at once, and while it could be argued that Continental philosophy texts are difficult enough without drawing attention to such minutiae as untranslatable words, the purpose of differential translation is not only to make translation visible for its own sake, but to expose the functioning of polysemy in philosophical concept formation.

When authors make explicit claims, their translators have their first duty in expressing those claims. Only afterwards can they express the meaningful connotations that form what Antoine Berman calls "underlying networks of signification" (Berman 2000:292). But German philosophers often utilize the persuasive force of these networks to the extent that we cannot adequately evaluate an author's work when a translation severs these networks. Even if translators do wish to capture the rhetorical dimensions of texts, they may undervalue the role of a particular word's suggestive etymology or other polysemy when philosophers do not thematize a suggestive word as a term worthy of special attention. The problem is exacerbated by the fact that it remains unconventional for translators to show special attention to language that the author has not marked as terminology.

Theorist of terminology Pamela Faber has observed scientists' rhetorical habit of employing verbs morphologically related to their abstract terms (2015: 18). The

13. I take Roland Barthes' distinction between plaisir and jouissance to mark the difference between entrancing and startling reading experiences (Barthes 1982). Translators of philosophy may feel ambivalent about which experience to foster. For instance, David McLintock, the recent translator of Freud's "The Uncanny," uses in-text annotations even more interruptive than differential translation would be for Freud's untranslatable unheimlich (eeire, uncanny, unhomely). And he apologizes for the words "inserted tiresomely often in square brackets" (Freud 2003: lxiii). 
German terms Grund, Strom, and naheliegend evoke verbs with differing lexical aspects: the accomplishment "to found" (gründen), the atelic action "to stream" (strömen), and the static action "to lie" (liegen). But does this covert dimension of meaning work more or less powerfully when our conscious attention to the word is diminished because the word is not a term? The translation question is whether to mask or to reveal this dimension of analytical language, that is, to translate technical terms consistently in order to mark them or differentially in order to exhibit their polysemy - and furthermore whether only those words marked clearly as terms deserve this special attention. Twentieth century phenomenology relies extensively on "de-lexicalization" - as Paul Ricœur describes the defamiliarization of familiar words by evoking suggestive etymology (1977:292). ${ }^{14}$ Translations should ideally exhibit explicitly terminological metaphors, like Husserl uses; de-lexicalized dead metaphor terms, like Heidegger uses; and de-lexicalized dead metaphor non-terms, like Blumenberg uses. The translator may express these images by many routes: annotations, paraphrase, foreign words in brackets, and with the above techniques accompanied by differential translation of recurrent polysemous words. It might make for a distracting reading experience if too many words were treated this way, but this at least presents the surest strategy for showing how much German philosophy depends on the German language.

Differential translation communicates de-lexicalization handily by conveying a word's abstract meaning when necessary and the images latent in etymology when possible. The effect requires the foreign word in brackets. Freud's early translators translated the word Nachträglichkeit differently ("delay," "belatedness," "deferred action," etymologically "carried-after-ness") without putting the foreign word in brackets because they did not read it as a specialized term. Jean Laplanche and J.-B. Pontalis lament the inconsistent translations of Nachträglichkeit since inconsistency makes it "impossible to trace its use" within Freud's texts and between them (1973: 111). Presenting Freud's lexicon consistently, however, would have the drawback of concealing literary allusions and everyday connotations in Freud's language. With this in mind, Adam Phillips, general editor for the New Penguin Freud series, commissioned a team of translators whom he wanted to come to "no consensus about technical terms, each of the translators writing a preface in which they might say something about choices made..." (Phillips 2007). Translators do future reception a service if they mark repeated source text word and translate

14. David Charlston advocates translating Hegel's doppelsinnig consistently with "ambiguous" so that the reader notices that Hegel develops this concept as a term (Charlston 2012:35). Differential translation would reveal more: the etymology of doppelsinnig suggests "double-sensed" whereas its ordinary denotation is "ambiguous," which suggests indeterminate meaning rather than multiple senses. 
for varied meanings, by translating polysemous words by context while giving the original word in brackets. Bracketing foreign words is already widespread among translators working from English into other languages, where English terms are presumed to be better known than the source language words, but combining the foreign word with translations that vary at each occurrence - what I call differential translation - is not common in translation practice yet. Encountering differentially translated texts would challenge future scholars to evaluate the unity of the concept behind the word. Yet with no criterion for finding words that deserve this special kind of translation, translators must trust their own reading and decide which words bespeak concepts yet to be fully articulated in the target language's theoretical vocabulary.

The recent discourse of philosophical "untranslatables" elicits the question: which particular words deserve translators' special attention? For Barbara Cassin, an "untranslatable" arises in the translation process when a word "creates a problem, to the extent of sometimes generating a neologism, or sometimes imposing a new meaning on an old word" (2014: xvii). Cassin registers untranslatables in words that accumulate meanings along their textual histories, but any word that sets a translator into aporia meets her basic criterion for the designation "untranslatable." This article has shown that untranslatables often lurk within the imagistic connotations of abstract vocabulary in languages whose etymologies are more transparent than those of the target languages. ${ }^{15}$ Since we can neither catalog all untranslatables nor assign thorough criteria for their discovery in source texts, translators must find a way to mark untranslatables conspicuously so that readers can notice and reflect on problematic words. A strategy like differential translation would let translators go on translating so that readers can go on philosophizing.

\section{References}

Appiah, Kwame Anthony. 1993. “Thick Translation.” Callaloo 16 (4): 808-19. doi:10.2307/2932211 Barthes, Roland. 1982. Le Plaisir du Texte. [The Pleasure of the Text.] Paris: French \& European Pubns.

Beals, Kurt. 2014. "Alternatives to Impossibility: Translation as Dialogue in the Works of Paul Celan.” Translation Studies 7 (3): 284-99. doi:10.1080/14781700.2013.866904

Benjamin, Andrew E. 1989. Translation and the Nature of Philosophy: A New Theory of Words. New York: Routledge.

15. A similar insight inspired recent encyclopedia of metaphors in German, another display of the systematic tendency in Continental philosophy: the Wörterbuch der philosophischen Metaphern (Konersmann 2007). 
Benjamin, Walter. 2000. "The Task of the Translator: An Introduction to the Translation of Baudelaire's Tableaux Parisiens.” In The Translation Studies Reader, edited by Lawrence Venuti. New York: Routledge.

Berman, Antoine. 2000. “Translation and the Trials of the Foreign." In The Translation Studies Reader, edited by Lawrence Venuti, 284-97. New York: Routledge.

Blumenberg, Hans. 1950. "Die ontologische Distanz: eine Untersuchung über die Krisis der Phänomenologie Husserls." [The Ontological Distance: An Investigation on the Crisis of Husserl's Phenomenology.] Habilitationsschrift. Kiel.

Blumenberg, Hans. 1966. Die Legitimität der Neuzeit. [The Legitimacy of the Modern Age.] Frankfurt am Main: Suhrkamp.

Blumenberg, Hans. 1983. The Legitimacy of the Modern Age. Studies in Contemporary German Social Thought. Cambridge, MA: MIT Press.

Blumenberg, Hans. 1987. Das Lachen der Thrakerin: eine Urgeschichte der Theorie. [The Laughter of the Thracian Woman: A Protohistory of Theory.] Suhrkamp Taschenbuch Wissenschaft. Frankfurt am Main: Suhrkamp.

Blumenberg, Hans. 2010. Theorie der Lebenswelt. Berlin: Suhrkamp.

Blumenberg, Hans. 2012. Quellen, Ströme, Eisberge. Edited by Ulrich v. Bülow and Dorit Krusche. Berlin: Suhrkamp.

Blumenberg, Hans. 2015. The Laughter of the Thracian Woman: A Protohistory of Theory. Translated by Spencer Hawkins. London; New York: Bloomsbury Academic.

Cassin, Barbara, Steven Rendall, and Emily S. Apter. 2014. Dictionary of Untranslatables a Philosophical Lexicon. Princeton: Princeton University Press.

Charlston, David. 2012. “Translating Hegel's Ambiguity: A Culture of Humor and Witz." In Translation and Philosophy, edited by Lisa Foran. Intercultural Studies and Foreign Language learning, 1663-5809. New York: Peter Lang.

Charlston, David. 2014. “Translatorial Hexis.” Radical Philosophy, no. 186 (August). https://www. radicalphilosophy.com/article/translatorial-hexis.

Derrida, Jacques. 1973. Speech and Phenomena, and Other Essays on Husserl's Theory of Signs. Northwestern University Studies in Phenomenology \& Existential Philosophy. Evanston: Northwestern University Press.

Derrida, Jacques. 1991. Of Spirit: Heidegger and the Question. Translated by Geoffrey Bennington and Rachel Bowlby. 1 edition. Chicago: University of Chicago Press.

Derrida, Jacques. 2001. "What Is a 'Relevant' Translation?” Translated by Lawrence Venuti. Critical Inquiry 27 (2): 174-200. doi:10.1086/449005

Faber, Pamela. 2015. "Frames as Framework for Terminology." In Handbook of Terminology, edited by Hendrik J. Kockaert and Frieda Steurs, 14-33. Philadelphia: John Benjamins.

Foran, Lisa. 2015. “An Ethics of Discomfort: Supplementing Ricoeur On Translation.” Études Ricoeuriennes / Ricoeur Studies 6 (1): 25-45. doi:10.5195/errs.2015.285

Freud, Sigmund. 2003. The Uncanny. Edited by Hugh Haughton. Translated by David McLintock. London: Penguin.

Genette, Gérard. 1997. Palimpsests: Literature in the Second Degree. U of Nebraska Press.

Groth, Miles. 2004. Translating Heidegger. Humanity Books.

Haverkamp, Anselm, and Dirk Mende, eds. 2009. Metaphorologie: Zur Praxis einer Theorie. [Metaphorology: On the practice of a theory.] 1. Aufl. Frankfurt am Main: Suhrkamp.

Heidegger, Martin. 1969. The Essence of Reasons. Northwestern University Studies in Phenomenology \& Existential Philosophy. Evanston, IL: Northwestern University Press. 
Heidegger, Martin. 1974. “The Principle of Ground." Translated by Keith Hoeller. Man and World 7 (3): 207-22. doi:10.1007/BF01248755

Heidegger, Martin. 1991. Nietzsche, Vol. 1: The Will to Power as Art, Vol. 2: The Eternal Recurrence of the Same. Translated by David Farrell Krell. San Francisco: HarperOne.

Heidegger, Martin. 1996. The Principle of Reason. Translated by Reginald Lilly. Indiana University Press.

Heidegger, Martin. 1997. Kant and the Problem of Metaphysics. Translated by Richard Taft. Indiana University Press.

Heidegger, Martin. 2008. Being and Time. Translated by John Macquarrie and Edward Robinson. Reprint. Harper Perennial Modern Classics.

Husserl, Edmund. 1964. Phenomenology of Internal Time Consciousness. Edited by Martin Heidegger. Translated by James S. Churchill. 1st edition. Bloomington: Indiana University Press.

Husserl, Edmund. 1981. Husserl, Shorter Works. Edited by Peter McCormick and Frederick Elliston. Notre Dame, IN: University of Notre Dame Press; Brighton, Sussex: Harvester Press.

Husserl, Edmund. 2001. Logical Investigations. Translated by Dermot Moran. Psychology Press.

Jakobson, Roman. 1971. "On Linguistic Aspects of Translation.” In Selected Writings: Word and Language, 260-64. Berlin: Walter de Gruyter.

Koller, Werner. 2004. "Untranslatable Words - Translatable Texts? Or, Translatable Words Untranslatable Texts?” FORUM 2 (2): 59-72.

Konersmann, Ralf. 2007. Wörterbuch der philosophischen Metaphern. [Dictionary of Philosophical Metaphors.] Darmstadt: Wissenschaftliche Buchgesellschaft.

Lakoff, George, and Mark Johnson. 1980. "The Metaphorical Structure of the Human Conceptual System.” Cognitive Science 4: 195-208. doi:10.1207/s15516709cogo402_4

Laplanche, Jean., and J. B. Pontalis. 1973. The Language of Psycho-Analysis. Translated by Donald Nicholson-Smith. International Psycho-Analytical Library. London: Hogarth Press.

Laplanche, Jean. 1993. “The Freud Museum Seminar.” In Jean Laplanche: Seduction, Translation and the Drives: A Dossier, edited by Martin Stanton, First edition, 41-64. London: Ica Editions.

Machiavelli, Niccolò. 1977. The Prince: A New Translation, Backgrounds, Interpretations. Translated by Robert M. Adams. New York: Norton.

Merleau-Ponty, Maurie. 2002. Phenomenology of Perception. New York: Routledge.

Nietzsche, Friedrich Wilhelm. 1995. Thus Spoke Zarathustra: A Book for All and None. Translated by Walter Arnold Kaufmann. New York: Modern Library.

Phillips, Adam. 2007. “After Strachey: Translating Freud." London Review of Books, October 4.

Plato. 1940. Platon-Brevier, grossenteils in neuen Übersetzungen. [Plato Digest, Largely in New Translations.] Translated by Karl Kindt. Selections. German. [Dessau]: K. Rauch.

Plato. 1977. Theaetetus, Sophist. Translated by Harold North Fowler. Cambridge, Mass: Harvard University Press.

Quine, W.V. 1960. Word and Object. Studies in Communication. [Cambridge]: Technology Press of the Massachusetts Institute of Technology.

Rand, Nicholas. 1990. “The Political Truth of Heidegger's 'Logos': Hiding in Translation.” PMLA 105 (3): 436-47. doi: 10.2307/462893

Ricoeur, Paul. 1977. The Rule of Metaphor: Multi-Disciplinary Studies of the Creation of Meaning in Language. Translated by Robert Czerny. La Métaphore vive. English. Toronto: University of Toronto Press. 
Robinson, Douglas. 1991. The Translator's Turn. Baltimore: Johns Hopkins University Press.

Robinson, Douglas. 2001. Who Translates?: Translator Subjectivities Beyond Reason. SUNY Press.

Schalow, F., ed. 2011. Heidegger, Translation, and the Task of Thinking Essays in Honor of Parvis Emad. Contributions to Phenomenology, 0923-9545; 65. Dordrecht: Springer Science+Business Media B.V. doi:10.1007/978-94-007-1649-0

Stellardi, Giuseppe. 2000. Heidegger and Derrida on Philosophy and Metaphor: Imperfect Thought. Philosophy and Literary Theory. Amherst, NY: Humanity Books.

Venuti, Lawrence. 1998. The Scandals of Translation: Towards an Ethics of Difference. New York: Routledge. doi:10.4324/9780203269701

Author's address

Spencer Hawkins

Bilkent University

Middle Campus

Lojman 105/11

Bilkent, Ankara 06800

Turkey

spenseur@umich.edu

\section{Biographical notes}

Spencer Hawkins is an Assistant Professor in the Program for Cultures, Civilizations, and Ideas at Bilkent University in Ankara, Turkey and is the translator of Hans Blumenberg's The Laughter of the Thracian Woman. 